\title{
Alignment of short reads to multiple genomes using hashing
}

\author{
Quang $\operatorname{Tran}^{1 *}$, Vinhthuy Phan ${ }^{2}$ \\ From UT-KBRIN Bioinformatics Summit 2014 \\ Cadiz, KY, USA. 11-13 April 2014
}

\section{Background}

Recent advances in biotechnology have enabled highthroughput sequencing of genomes based on large numbers of short reads. Current methods [1,2], however, depend mostly on aligning reads to only one reference genome at a time, making it difficult to differentiate sequencing errors from single nucleotide variants (SNV).

\section{Materials and methods}

Inspired by [3], we propose a new method that attempts to take advantage of multiple genomes and SNV information to align reads. This approach is promising in that it allows us to distinguish between sequencing errors and SNV. Our proposed alignment algorithm uses read fragments to identify seeds and extend these seeds to find occurrences of reads in the genome. In this study, we have developed and implemented an algorithm using multiple genomes that captures genomic variations, indexes the multiple genomes and operates short read alignment on a collection of genomes. The preliminary result was validated on Aspergillus fumigatus.

\section{Authors' details}

${ }^{1}$ Bioinformatics Program, University of Memphis, Memphis, TN 38152 USA

${ }^{2}$ Department of Computer Science, University of Memphis, Memphis, TN 38152, USA.

Published: 29 September 2014

\section{References}

1. Gontarz PM, Berger J, Wong CF: SRmapper: a fast and sensitive genomehashing alignment tool. Bioinformatics 2013, 29(3):316-321.

2. $\quad$ Langmead B, Salzberg SL: Fast gapped-read alignment with Bowtie 2. Nat Methods 2012, 9(4):357-359.

3. Huang L, Popic V, Batzoglou S: Short read alignment with populations of genomes. Bioinformatics 2013, 29(13):i361-i370.

* Correspondence: qmtran@memphis.edu

${ }^{1}$ Bioinformatics Program, University of Memphis, Memphis, TN 38152 USA

Full list of author information is available at the end of the article
doi:10.1186/1471-2105-15-S10-P23

Cite this article as: Tran and Phan: Alignment of short reads to multiple genomes using hashing. BMC Bioinformatics 2014 15(Suppl 10):P23.
Submit your next manuscript to BioMed Central and take full advantage of:

- Convenient online submission

- Thorough peer review

- No space constraints or color figure charges

- Immediate publication on acceptance

- Inclusion in PubMed, CAS, Scopus and Google Scholar

- Research which is freely available for redistribution

Submit your manuscript at www.biomedcentral.com/submit
() Biomed Central
C Biomed Central

(c) 2014 Tran and Phan; licensee BioMed Central Ltd. This is an Open Access article distributed under the terms of the Creative Commons Attribution License (http://creativecommons.org/licenses/by/4.0), which permits unrestricted use, distribution, and reproduction in any medium, provided the original work is properly cited. The Creative Commons Public Domain Dedication waiver (http://creativecommons.org/publicdomain/zero/1.0/) applies to the data made available in this article, unless otherwise stated. 